\title{
BOJACK HORSEMAN, OR THE EXHAUSTION OF POSTMODERNISM AND THE ENVISIONING OF A CREATIVE WAY OUT
}

\author{
Raúl SÁNCHEZ SAURA* \\ Eton College, Modern Languages and Cultures Department, Windsor, Berkshire \\ SL4 6DW, England, United Kingdom
}

Received 2 January 2019; accepted 22 October 2019

\begin{abstract}
Postmodernism, as a hegemon, has determined the cultural coordinates of audiovisual products in the last decades. Since 2008, some shows have creatively questioned its main principles, such as superficiality, cynicism-bordering irony and the lack of alternative to all this (Francis Fukuyama's end of history). BoJack Horseman (executive producers Raphael Bob-Waksberg, Noel Bright, Steven A. Cohen, Blair Fetter, Jane Wiseman, Will Arnett, Aaron Paul and Andy Weill, 2014-2019), the Netflix series, follows the struggles in the life of the eponymous character, star of the 1990s sitcom Horsin' Around, and his exhaustion from the vacuity of life in Hollywood, United States. Surrounded by his peculiar entourage, viewers witness all sorts of unimportant nonsense and risible statements to ultimately engage in the story and meet old characters under a new light. After many seasons, our understanding of them changes and we are forced to revaluate our consideration of them, engaging sympathetically and leaving behind an individualist detachment some authors, like David Foster Wallace, criticised in the past. This only comes to happen because of the creative use of animation, the script and characters.
\end{abstract}

Keywords: BoJack Horseman, creativity, cynicism, Fukuyamaism, hegemony, irony, postmodernism.

\section{Introduction. Back in the 1990s: cynicism and immovability in animated series}

As a Netflix show on air since 2014, BoJack Horseman belongs to the post-2008 context of exhaustion from some of the main tenants of the postmodern hegemony. This exhaustion can be traced to the questioning of these during the 2000s: 9-11, the Iraq War, the anti-imperialist governments in Latin America and the 2007/2008 economic crisis seemed to overrule any notion of an "end of history". That major conflicts had ended after the triumph of capitalism over state socialism could hardly be believed in the face of so many areas of confrontation. Furthermore, some rebellion against the characteristic traces of techno-optimism and demobilisation proper of mainstream culture could be found within mainstream films: Fight Club (director David Fincher, 1999) and V for Vendetta (director James McTeigue, 2005) have

*Corresponding author. E-mail: raulsanchezsaura@hotmail.com 
been instrumentalised in recent years by anti-globalisation movements and forces from quite different political traditions. Yet, if any cultural product has criticised postmodern culture while perfectly embodying it, that is animated series. Shows like The Simpsons (executive producers James L. Brooks, Matt Groening, Al Jean, Matt Selman, John Frink, Sam Simon, Mike Reiss, David Mirkin, Bill Oakley, Josh Weinstein, Mike Scully, George Meyer, Carolyn Omine, Tim Long and Ian Maxtone-Graham, 1989-2019) and South Park (executive producers Trey Parker, Matt Stone, Brian Graden, Debbie Liebling, Frank C. Agnone II, Bruce Howell and Anne Garefino, 1997-2019) have exposed a cynical sense of humour and pointed out the faults of Western society while ridiculing any attempts to change them. The Simpsons resetting their house after it burns down, suffers from a flood, or any other catastrophe, from one episode to the next, as if nothing had ever happened, serves as an example here.

These shows' ironic comments on society, religion and politics while having its characters changing nothing ultimately leads one into thinking that there is nothing that can be done since change seems to be impossible. This feeling, one would claim, derives from one's acts entailing no consequences and living conditions for the series' characters remaining rather the same as before. Time after time after time, the house will be reset no matter what. Instead of changing anything, statements or actions prove to the perennial nature of everyday day: no matter what adventures he incurs into, Homer Simpson keeps working for Mr. Burns. No matter any episodes showing Mr. Burns', or Moe Szyslak's, more tender side: next episode they will keep acting as selfish, mean individuals. No character development, barely any consistent narrative arch could be found in 1990s most popular series, both animated (The Simpsons, South Park), our focus today, but also live action ones (Friends (executive producers David Crane, Marta Kauffman, Kevin S. Bright, Michael Borkow, Michael Curtis, Adam Chase, Greg Malins, Wil Calhoun, Scott Silveri, Shana Goldberg-Meehan, Andrew Reich and Ted Cohen, 1994-2004), Frazer (executive producers Peter Casey, David Lee, David Angell, Christopher Lloyd, Kelsey Grammer, Joe Keenan, Dan O'Shannon, Mark Reisman, Rob Hanning, Sam Johnson, Chris Marcil, Lori Kirkland Baker and Jeffrey Richman, 19932004)). But in the case of the former, full as they were of a scathing social critique, viewers were left with the feeling that no matter your own critical outlook to the world, there is nothing you can do. Springfield will always use energy coming from Mr. Burns' nuclear power plant in spite of its proven lack of security measures. 20 years after she became a vegetarian, Lisa Simpson has never convinced anyone else to join her.

BoJack Horseman's quite radical departure from this immovable paradigm deserves some spaces to be commented and expanded upon. Now, before the conclusion, I will firstly dedicate my focus to elaborating on the social dimension to this Netflix show: the unfolding of processes, the references to real life and, interestingly, the agency our characters have when it comes to affecting these processes. This agency is not only tangible but its influence can usually be traced back over the next episodes. There is a sense of continuity, a continuum of experiences that have nothing to do with traditional animated shows. Here we can enjoy narrative arches and character developments as we usually only would in a celebrated HBO show. All of this while commenting on the faults of contemporary society and having our characters try to correct whatever is wrong in their lives to find some balance, or meaning, society cannot provide for us. 
Then on the next section, this idea of agency will continue playing a major role for understanding the genius of BoJack Horseman. We will see the treatment of time and history in relation to Fukuyama's idea of the end of history which I introduced a couple of paragraphs above. Some scenes and evolutions of very specific characters confront some of the core ideas of this concept, so key for understanding postmodernism. Since it maintains that our society is isolated from all previous ones, and that the future belongs to scientific and technological advances companies, rather than people, have a say in, the proliferation of weapons of mass escapism as we now see everywhere becomes more understandable. But our favourite horse, unsurprisingly, will prove there are always alternatives.

Summarily, here I will cover the show's social critique, complex characters and storylines and criticism of a concept with wide range influences in both philosophy of history and geopolitics. That I will do this while leaving aside the work on animation or some of the most intimate moments in the show attests to the creative richness of it, able to merge very different elements in quite a successful way and leave its mark on viewers.

\section{BoJack Horseman: A creative departure}

Departing vigorously from the repetitive narrative of these previous animated series, free from any growth, BoJack Horseman not only criticises contemporary society beyond superficialities, but it also offers options on how to transcend them. This is one of the sources of its creativity. Here we find a new generation of shows which, in the last half of the 2010s, have more readily reinvigorated the debate on the problems the American society faces ${ }^{1}$, sanctioning the maintenance of affairs as usual. Going through some brief list, and in the case that occupies us here, we can mention episodes like "BoJack Hates the Troops", "Hank After Dark", "Brrap Brrap Pew Pew”, “Thoughts and Prayers" or "BoJack the Feminist" as examples of this deeper, discussion-inviting critique. The fact that the series not only expresses some public discussions going on at the time of emission, but also returns many of their criticisms to the other side of the screen should not go overlooked. Despite its postmodern blending of both tragedy and comedy ${ }^{2}$, of humans and anthropomorphic animals as characters - and its abundant cultural references, summarily its postmodern roots, we will see how this show proposes creative alternatives to it.

The aim of this essay is to show how some mainstream cultural products are starting to openly criticise society in a non-cynical way, arguably for the first time in decades. This open criticism might entail an erosion of the postmodern edifice, since it recovers discourses not so present in mainstream media while propagating them to millions, previously unaware of them. If this evolves into a new cultural hegemon different from postmodern values, we will need to look back at the roots of this shift in the common sense. Our show, in however humble a way, is paving the way for this trend to accelerate its pace, or so I will try to prove

\footnotetext{
${ }^{1}$ As it indicates the struggles facing the strongest nation on Earth, this critique is of interest for the extended West.

${ }^{2}$ I should insist that, in spite of its hilarious sense of humour of the series, it is primarily a series on depression. This has led Jenny Jaffe (2015) to label it a "sadcom", a move that further illustrates how the show follows a different trajectory from traditional sitcoms. We can reference Zack Handlen (2015) here since it triggered Jaffe's article and dwells on the same topics - a future stream of literature on this field should be expected.
} 
by firstly commenting on its anti-cynical sense of humour and afterwards, on its critique of the end of history, or Fukuyamaism. This latter point is important, since it has cemented the idea that there exists no alternative to the current hegemon by insisting that no force can present a challenge to $\mathrm{it}^{3}$. History is written linearly, and the future can be as clearly visualised as the present, or so the ranting goes. Incidentally, we will also see how certain thinkers, like Foster Wallace, previously questioned these postmodern values too, especially anything related to cold individualism and superficiality, problems that may not need much presentation since they refer to both the cultural and social spheres.

Back to our series, BoJack Horseman takes place at the very heart of the celebrity culture of Los Angeles, United States. Of the five main characters, two are well-known actors for their roles in 1990s sitcoms (BoJack ${ }^{4}$ and Mr. Peanutbutter, a yellow Labrador) and the other three conform their entourage: Princess Carolyn, a cat, is their agent; Diane Nguyen is Mr. Peanutbutter's wife and BoJack's biographer, and Todd Chavez is BoJack's flatmate and everyone's errand boy. In this society of the image in which everyone is pending on the next trend and image has become queen, superficiality reigns triumphant, a sign of the postmodernity of this context as it is, as Fredric Jameson (1991, p. 9) defined it, "in its most literal sense", "a supreme feature of all the postmodernisms". The shallowest of the five, Mr. Peanutbutter summarises this era's mentality when he says: “The universe is a cruel, uncaring void. The key to being happy isn't a search for meaning. It's to just keep yourself busy with unimportant nonsense, and eventually, you'll be dead". That he says this so casually speaks volumes on how deep this unchallenging society's waters run, and how accepting of their lack of agency people have become. And here we should recover Foster Wallace's observation that contemporary culture, through its disbelief of grand narratives and vacuous entertainment with unconstructive habits, can become extraordinarily exhausting:
"[...] irony, entertaining as it is, serves an exclusively negative function. It's critical and destructive, a ground-clearing. Surely this is the way our postmodern fathers saw it. But irony's singularly unuseful when it comes to constructing anything to replace the hypocrisies it debunks. This is why Hyde seems right about persistent irony being tiresome. [...] one ends up feeling not only empty but somehow [...] oppressed" (The Free Library, 1993).

This unsurmountable lightness of being, which makes every single event subject to viralization in the face of the most thoughtless uncritical crowd possible can make one character either become the new Governor of California, United States without understanding how that came to happen or feel utterly alone when everyone is copying his usual clothing ${ }^{6}$. No one will show any surprise or disbelief at this since no one possesses any clear rules sanctioning how society should operate, anything seems to be permitted. You can direct your attention to a certain issue and, once you grow tired of it, move on to something else. This

\footnotetext{
3 "What we may be witnessing is not just the end of the Cold War, or the passing of a particular period of postwar history, but the end of history as such: that is, the endpoint of mankind's ideological evolution and the universalisation of Western liberal democracy as the final form of human government" (Fukuyama, 1989, p. 3).

${ }^{4}$ Alissa Chater (2015) is recommended for a contrast on life in Horsin' Around, BoJack's sitcom, and life in BoJack Horseman.

${ }^{5}$ Episode 12 of the first season, or S01E12.

${ }^{6}$ In both cases I am referring to Todd Chavez and to events in the first and the last episodes of season 4, respectively.
} 
undoubtedly leads to the most laughable moments in the show out of their sheer stupidity and is rich in slapstick comedy. That such random social forces govern over individuals further illustrates this point: this postmodern life leads to some feeling of oppression. Even those characters that belong to this superficiality, such as the eponymous character, a depressed horse, want to escape it at some points. What we get from BoJack Horseman is therefore an animated show with anthropomorphic animals, the most hilarious lines possible and a poignant criticism of contemporary times, while exploring the tortured psychology of its main characters. The ability to mix all of these elements successfully, and to include certain creative moments animation-wise, such as in S01E11, S03E04, S03E11, S04E02, S04E11 or S05E11, makes the case for the role creativity plays in order not only to deliver a fine work of art but also for it to have a transcending message by establishing different layers of understanding. Intradiegetically, and specifically to BoJack, he can usually see through the ridiculousness of certain situations: he realises that Vincent Adultman is actually three kids inside a trench coat. He sometimes even attempts to engage in serious conversations, rendering this general feeling of loneliness even more present.

An example for how this main character seeks to express a thought that questions some long-held assumptions in American society should be taken as an early indicator of the show's ambition to make a stand against the most obnoxious elements of the postmodern hegemony, part of its creativity. When on live television, after the muffins-related argument at the supermarket with a former military, he surprises everyone by stating:

"I don't agree to [the military being heroes]. Maybe some of the troops are heroes but not automatically. I'm sure that a lot of the troops are jerks. Most people are jerks already, and it's not like giving a jerk a gun and telling him it's OK to kill people suddenly turns that jerk into a hero" (S01E02).

The mass reactions against him for confronting the Manichaean admiration for the United States military forces him to apologise to this soldier, Neal McBeal the United States Navy SEAL. Appropriately for the general stupidity of the situation, which only BoJack perceives, it is decided that he should apologise in an episode of "Peanutbutter and Jelly", Mr. Peanutbutter's reality show à la Kardashians. Speaking under conditions cutting away his freedom of expression, he recurs to verbal irony to convey his authentic message, questioning many aspects of his circumstance, which barely no one has regarded as awkward in any moment:

"You're [McBeal] a hero. The troops are all heroes, every single one. [...] And I don't believe saying that cheapens the word and actually disrespects those we mean to honour by turning real people into political pawns. [...] Also, I am not deeply ambivalent about a seemingly mandated celebration of our military by a nation that claims to value peace, telling our children that violence is never the answer, while refusing to hold our government to the same standard. [...] Furthermore, I do not find it unbelievably inappropriate that this conversation is taking place on reality television, a genre which thrives on chopping the complexities of our era into easily digestible chunks of empty catchphrases. [...] And finally, I don't [...]" (S01E02).

Mr. Peanutbutter interrupts this speech by getting his head in a bucket, exemplifying how postmodernism does not seek to engage in earnest conversation which could weaken its shallow paradigm. Within a matter of seconds, we go from a deep speech to a simple gag without 
feeling that the nature of the show is hurt in any way, since BoJack Horseman encompasses both elements. It is all part of a larger whole. And the ability of the creative team to keep all these dishes spinning deserves a more careful analysis in the future. When comparing this discourse to, for example, The Simpsons S07E13, depicting George H. W. Bush as simple as any simple man, the only lesson one can extract is that anyone can become the United States President ${ }^{7}$. And, of course, many more examples exist of this infantilised society: everyone starts calling "Hollywood, Hollywood!" after BoJack steals the giant "D" with no second thought at all (S01E06). No one is surprised in discovering that J. D. Salinger faked his own death and is now returning with a quiz show titled "Hollywoo Stars and Celebrities: What Do They Know? Do They Know Things? Let's Find Out!” (S02E06). This unquestioning relativisation of everything as possible, this generalised "why not?" attitude in relation to every single event, steers characters toward exhaustion: even those who readily accept the rules of the game. Some nights, Princess Carolyn finishes her day unsatisfied by the relentless lack of meritocracy at her agency, Todd Chavez eventually grows tired of BoJack's recklessly irresponsible behaviour, BoJack cannot cope with a 24/7 superficial world which only takes him for a buffoon from that 1990s show. Sometimes, their struggles may seem all too real, and making that possible with an animated horse can only be taken as an artistic feat.

\section{History, its end and depressed horses}

The previous pages have hopefully illustrated the richness of the show when it comes to satire, social critique and all too real experiences that may awe viewers. When it comes to the treatment of historical time, and of the interrelation between past and present, we are now about to see that pretty much more of the same comes to occur. This achievement of the show, able to inspire laughs during sad moments and move during light ones, further hints at its creative nature. It is after all our intention to show and comment upon the different elements whose mixing, alongside the work on animation, entails for this creative appreciation. As a character, BoJack commits many mistakes and, after his lowest point at the end of season three, he decides to hide in anonymity for a while, returning to his mother's old family holiday residence in Michigan, United States. During the previous three seasons, BoJack's parents have been shown as cruel and unloving to him. Consequently, the relationship has never been $\operatorname{good}^{8}$ and, as such, his mother has always been for the viewer a flatly lousy person. However, in this episode I refer to, "The Old Sugarman Place" (S04E02), we as viewers not only get to know more about BoJack's family history but also assist to Fukuyamaism receiving a retort from the show. BoJack is hiding there after the death of his daughter figure, Sarah Lynn, fellow star

\footnotetext{
7 A point also made in BoJack Horseman S04E01, the first episode aired after the 2016 elections, but here in relation to the California state elections. The incumbent Governor of California ends up competing for the position in a ski race against Mr. Peanutbutter after constitutional reform. That the show mocks the banal electoral process and only some characters like Diane Nguyen realise the absurdity of the moment stands for a critique of the vulgarisation of United States. The Simpsons offers no hope, no alternative, not even criticises that a basic man - as the show depicts him - reached such high office. The social critique of BoJack Horseman departs from the immobilism of the latter, along the lines of Foster Wallace from This Is Water (2019).

8 In the first three seasons, the only time his mother did not behave in a mean way to him but was actually honest, she told him: "You were born broken, BoJack. That is your birthright. [...] You are BoJack Horseman, there is no cure for that" (S02E01).
} 
in his 1990s series, Horsin' Around. Meanwhile, the broken house gets us viewers back to the 1940s, when BoJack's mother, Beatrice, was a little girl and her older brother, Crackerjack, died in World War II, destabilising her mother. BoJack's grandmother, after receiving the news of her son's death, desperately seeks to find Crackerjack's childhood blanket.

BoJack Horseman retorts to Fukuyama in his statement that present and past (usually the Cold War) now have nothing in common and extra-human forces - the markets, technological advancement - render us agentless in both the present and the future ${ }^{9}$. Here we can see the parallelisms between BoJack's condition and his grandmother's, how the faults and sins of grandparents haunt the parents, and those of the parents haunt their sons. We experience in one scene what we may refer to as abolished time, as the state of the house in the winter of 2016-2017 with BoJack freezing and that of the house in the 1940s coincide in the hall, and two different scenes take place simultaneously. While his ancestors interact among them, BoJack is alone watching the new American Dead Girl series on Sarah Lynn with his smartphone, Paul Giamatti playing him.

"Giamatti: Tell me, doc, is she gonna be OK?

Grandmother: I know it's here somewhere.

Grandfather: Darling, we've been through this. He doesn't need his blanket. [Beatrice leaves the hall.]

Doctor: There was nothing we could do.

Grandmother: I need to find it. He should've had it.

Giamatti: She's dead?

Grandfather: He is gone, honey. Even Blinky couldn't have stopped that Nazi's bullet.

Grandmother: Oh, Joseph, I failed him.

Giamatti: Oh doc, I let her down.

Doctor: This was bound to happen. That's just show business.

Grandfather: That's just war, honey. [Grandmother sobs.]

Beatrice [re-entering with a blanket]: Here it is, mother. I put it in the closet for safekeeping.

Grandmother: I never should have let him go.

Grandfather: Honey, no. If anyone's to blame, it's the Jews for peeving off Hitler so bad. ${ }^{10}$

Giamatti [singing the Horsin' Around song, sobbing]: Three little orphans. One, two, three. Without a home or a family tree [viewing interrupted by a call from Diane. BoJack does not take it and resumes the viewing.] We were lost. Now we're found. And we are [crying]. Oh God [Sobbing]!

Grandfather: Come on, let's head home. It's only ghosts here in the winter" (S04E02).

Past and present are connected in the destiny of different generations because of the relation of cause and consequence between them. In another memory, Beatrice promises to her grieving mother, who has just undergone a lobotomy, that she will never love the way she loved Crackerjack. This is the root of BoJack's problems with his mother. Through this scene of abolished time, we get an open window to the most memorable arch in the whole series, an emotionally charged moment, but also a reading that we can take in the context of the idea of the end of history. Since creativity has been understood time and time again here as

\footnotetext{
${ }^{9}$ Human idealism "will be replaced by economic calculation, the endless solving of technical problems, environmental concerns, and the satisfaction of sophisticated consumer demands" (Fukuyama, 1989, p. 17).

${ }^{10}$ In case it needs any explanation, this is just a pun on Western anti-Semitism and a way of lightening the scene's mood.
} 
the ability to successfully mix different elements and make the whole enjoyable from different perspectives, here we undoubtedly get a creative peak in the show.

BoJack Horseman further lambasts Fukuyamaism by reflecting on the agency of people to act in relation to the legacy they have received. While the 1940s storyline has taken place, BoJack has come to meet his neighbour, a dragonfly who has not overcome his wife's death and lives by clinging to his memories. Unwilling to meet the same end, he decides to demolish his old family house at the end of the episode after their joint effort to remake it took nearly a year. Thus, he exemplifies the agency of the present to change and depart course: he can overcome what happened to Sarah Lynn, try to become a better person and prevent that from ever happening again. As he readies the Sisyphean demolition, we can see the ghost of his mother, when a little girl, playing by the yard. He may escape from his family's spiral of self-destruction, but she never did and only grew bitter as she found no solution for the void she carried with her since that 1940s summer.

Beatrice will go on to star the best narrative arch in the whole of season four. By going through the memories of this now (2016-2017) demented old woman, we will find out the difficulty of living under the rule of her Mephistophelian father, of her marriage with BoJack's father and the personal decision she once took of helping out their maid. "Time's Arrow" (BoJack Horseman) is the title of episode 11 of the fourth season, in which we finally reach Beatrice's self and discover her true personality, rich history and heart. That the show redraws a previously plain character to make her stand as actually a good, caring mare makes the viewer realise the wrongness of previous assumptions, recovering Foster Wallace's assertion on the need to empathise with others. The possibility that everyone can redeem him or herself, that one's meanness does not necessarily express one's faults, forces the viewer to alter the way some characters are perceived, rendering them more complex than how they looked at first. This process can be said to occur with every single main character, and even with some secondary ones like Beatrice.

Returning to our main character, after his many mistakes and excesses, his obsessive, depressive nature, he has disappointed many. Not only those closest to him, but also Wanda Pierce, Charlotte Carson, Sarah Lynn, Herb Kazzaz, Penny Carson, Beatrice, Kelsey Jannings, Corduroy Jackson-Jackson, Emily, Ana Spanikopita, Neal McBeal the United States Navy SEAL, Bradley Hitler-Smith and surely others I do not remember now are disappointed or led astray by BoJack at some point. This includes anything between an argument on having "dips" on muffins to death. However, once season four ends, he is far from being the character who has made the most memorable mistakes. He actually helps Princess Carolyn on her new project in S04E12 and then we have Hollyhock Manheim-Mannheim-Guerrero-RobinsonZilberschlag-Hsung-Fonzarelli-McQuack which embodies the possibility of redemption for BoJack as his potential daughter. As one could imagine, he fails at that and she departs. In the end, it is revealed that she is not his daughter; they maintain a good, healthy relation of comradery that promises some sort of redemption, still ongoing after season 5, when he confronts some other ghosts of his, namely addiction. We therefore witness some character development that breaks away from previous animated shows and points at these characters' struggles to become better, happier people. This entails confronting certain evils (fears, past traumas, insecurities) that may resonate with the general audience, just like the society of the 
image BoJack Horseman constantly depicts is not that far from our reality when considering that a dog and a woman are married. This covered with some of the best comedy in contemporary television and some genuinely impressive animation that deserve their own analysis provide us with a valuable example of what creativity means and refers to.

\section{Conclusions}

The series, then, criticises the vacuity of postmodern society, dedicates some episodes to social critique ${ }^{11}$ and narratively attacks the rationale of Fukuyamaism, thus questioning many tenants of postmodernism: individualism, relativism and materialism. The lavish life at Hollywood does not ultimately entail happiness, but rather loneliness. In a society in which social relations are had through screens, people hardly escape from complete solitude, and the reset we see after every The Simpsons episode is rendered as unreal, empty. Unlike in other animated shows, in BoJack Horseman there is a memory of previous events. If a couch in BoJack's house is burned down, it remains burned down in the next episode: there is a historical continuity making present events understandable when we trace their anteriority: acts have consequences, something that goes against both the cultural resetting of procedural shows. It is here that we find the series' reply to Fukuyamaism, the never-ending link between past and present. That Fukuyama himself has also questioned his own idea (2016) further proves how eroded these postmodern pillars are.

But beyond the criticism of the roots of the postmodern hegemony, BoJack Horseman does offer creative alternatives that aim at overcoming it which, again, follow some of the core ideas seen in Foster Wallace's writings and speeches. This comes from its ability to make us empathise with animated anthropomorphic animals, to witness the representation of these profound contemporary issues in a cartoon, and certainly other elements we do not have time to analyse now, such as the most oneiric moments, further expanding on our characters' psyches. The show reveals that our protagonists can redeem themselves, and that they may be more complicated than thought of at first. One character may explain the behaviour of another one and thus their different fragments - selves, psyches, narrative arches - conform a unity. After the exhaustion of the apparel and the vacuous conversation and sexual exchanges, BoJack Horseman offers instead of materialism, generosity; instead of individualism, community; instead of irony, a return to sincerity. Many characters come to express their true feelings when they cannot go on. They include others into their group of friends in spite of their differences, even take them under their roof. After having survived a nightmare in S04E07, there is the refuge of the community and our five protagonists arrange having some lunch. Just like millions find and support each other in real life, with their ups and downs, characters here reencounter and try to help each other. One single person is part of something much more important. Cold individualism leads to solitude and competition, whereas human brains are wired for empathy. The exhaustion irony causes can be put to an end, and people can find each other, and common shelter for the coming winter.

\footnotetext{
${ }^{11}$ We have S01E02, S02E05, S02E07, S03E06, S04E01, S04E05 and certain narrative arches, like fracking in season 4, or the Cabracadabra App in season three.
} 


\title{
References
}

Chater, A. (2015). From Real Housewives to The Brady Bunch: Bojack Horseman finds its place. Kino: The Western Undergraduate Journal of Film Studies, 6(1). Retrieved from https://ojs.lib.uwo.ca/index.php/kino/article/view/6289/5051

Foster Wallace, D. (2019). This is water. Retrieved from http://metastatic.org/text/This\%20is\%20Water.pdf

Fukuyama, F. (2016). America: the failed state. Prospect. Retrieved from http://www.prospectmagazine. co.uk/magazine/america-the-failed-state-donald-trump

Fukuyama, F. (1989). The end of history? The National Interest, 16, 3-18.

Handlen, Z. (2015). BoJack Horseman, Rick and Morty, and the Art of Cynical Sincerity. AV Club. Retrieved from https://tv.avclub.com/bojack-horseman-rick-and-morty-and-the-art-of-cynical-1798283496

Jaffe, J. (2015). The rise of the sadcom. Vulture. Retrieved from https://www.vulture.com/2015/09/riseof-the-sadcom.html

Jameson, F. (1991). Postmodernism, or, the cultural logic of late capitalism. Durham: Duke University Press. https://doi.org/10.1215/9780822378419

The Free Library. (1993). E unibus pluram: Television and U.S. fiction. Retrieved from https://www. thefreelibrary.com/E\%20unibus\%20pluram\%3Atelevision\%20and\%20U.S.\%20fiction.-a013952319

\section{BOJACKAS RAITELIS, ARBA POSTMODERNIZMO IŠSEKIMAS IR KŪRYBINĖS IŠEITIES İŽVALGA}

\author{
Raúl SÁNCHEZ SAURA
}

\begin{abstract}
Santrauka
Postmodernizmas pastaraisiais dešimtmečiais hegemoniškai nulèmė audiovizualinių produktų kultūrines kategorijas. Nuo 2008 metų kai kurių pasirodymų metu buvo kūrybiškai nuginčyti jo pagrindiniai principai, tokie kaip paviršutiniškumas, su ironija besiribojantis cinizmas ir viso to atžvilgiu vyraujanti alternatyvų stoka (Franciso Fukuyamos istorijos pabaiga). Netflixo seriale BoJackas raitelis (vykdomieji prodiuseriai Raphaelis Bobas-Waksbergas, Noelas Brightas, Stevenas A. Cohenas, Blairas Fetteris, Jane Wiseman, Willas Arnettas, Aaronas Paulas ir Andy Weillas, 2014-2019) vaizduojamos vadinamojo personažo XX amžiaus 10-ojo dešimtmečio situacijų komedijos Kvailiojimas žvaigždès gyvenimo kovos ir jo išsekimas nuo gyvenimo Holivude (Jungtinès Amerikos Valstijos) tuštybès. Supami ypatingos aplinkos, žiūrovai tampa visokių nereikšmingų niekų ir juokingų pareiškimų liudininkais, kad galiausiai ịsitrauktų i pasakojimą ir senuosius personažus sutiktų naujoje šviesoje. Praejus daugeliui sezonų, keičiasi mūsų supratimas apie juos; esame priversti iš naujo įvertinti savąji jiems skiriamą dèmesí, užjaučiamai jais domėtis ir atsisakydami individualistinio atsiskyrimo, kurị kai kurie autoriai, tokie kaip Davidas Fosteris Wallace'as, kritikavo praeityje. Tai ịvyksta tik dèl kūrybiškai pasitelktos animacijos, scenarijaus ir personažų.
\end{abstract}

Reikšminiai žodžiai: BoJackas raitelis, kūrybiškumas, cinizmas, fukujanizmas, hegemonija, ironija, postmodernizmas. 